\title{
Phosphorylated histone H2A.x in porcine embryos produced by IVF and somatic cell nuclear transfer
}

\author{
Rodrigo C Bohrer, Limei Che, Paulo B D Gonçalves ${ }^{1}$, Raj Duggavathi and Vilceu Bordignon \\ Department of Animal Science, McGill University, 21111 Lakeshore Road, Ste-Anne-de-Bellevue, Quebec, \\ Canada H9X 3 V9 and ${ }^{1}$ Laboratory of Biotechnology and Animal Reproduction, BioRep, Federal University of \\ Santa Maria, Santa Maria, Rio Grande do Sul, Brazil
}

Correspondence should be addressed to V Bordignon; Email: vilceu.bordignon@mcgill.ca

\begin{abstract}
Phosphorylated histone H2A.x (H2AX139ph) is a key factor for the repair of DNA double-strand breaks (DSBs) and the presence of H2AX139ph foci indicates the sites of DSBs. In this study, we characterized the presence of H2AX139ph during in vitro development of porcine embryos produced by IVF and somatic cell nuclear transfer (SCNT). Pronuclear stage embryos produced by IVF had, on average, 9.2 H2AX139ph foci per pronucleus. The number of H2AX139ph foci was higher in the 2-cell-stage embryos than in the 4-cell-stage embryos fixed at $48 \mathrm{~h}$ post-fertilization. The percentage of H2AX139ph-positive nuclei was higher in SCNT embryos that were activated with ionomycin (ION) alone than in those activated with $\mathrm{ION}$ and strontium chloride $\left(\mathrm{ION}+\mathrm{Sr}^{2+}\right)$. A negative correlation was found between the percentage of $\mathrm{H} 2 \mathrm{AX} 139 \mathrm{ph}$-positive cells and the total number of cells per embryo in day 7 blastocysts produced by IVF or SCNT. Based on the detection of H2AX139ph foci, the findings of this study indicate that DSBs occur in a high proportion of porcine embryos produced by either IVF or SCNT; fast-cleaving embryos have fewer DSBs than slow-cleaving embryos; the oocyte activation protocol can affect DNA integrity in SCNT embryos; and better-quality blastocysts have fewer DSBs. We propose that the presence of H2AX139ph foci can be a useful marker of embryo quality.
\end{abstract}

Reproduction (2013) 146 325-333

\section{Introduction}

Embryo technologies such as IVF and somatic cell nuclear transfer (SCNT) have been applied to produce embryos in a number of species. Because pigs are physiologically similar to humans, there is growing interest in the use of these technologies to create special animal models for the study of physiopathological processes and xenotransplantation (Kues \& Niemann 2004, Kuwaki et al. 2005, Aigner et al. 2010). However, the development of IVF and SCNT porcine embryos is influenced by different factors, including oocyte quality, polyspermy, abnormal cell cycle interactions, deficient epigenetic reprogramming, and altered gene expression (Abeydeera et al. 2000, Bortvin et al. 2003, Lucifero et al. 2006, Niemann et al. 2008, Nascimento et al. 2010, Whitworth \& Prather 2010, Yoshioka 2011).

Oocyte activation is an important step for the success of SCNT. Abnormal activation can lead to cell cycle incompatibilities between the nuclear donor cell and the host cytoplast, which can compromise embryo development (Campbell 1999, Fulka \& Fulka 2007). Intra-oocyte calcium oscillations induced by the sperm trigger oocyte activation during normal fertilization (Fissore et al. 1992). Strontium chloride $\left(\mathrm{Sr}^{2+}\right)$ has been shown to induce calcium oscillations in oocytes, and it has, consequently, been used for oocyte activation in different species such as mouse, rat, bovine, and ovine species (Kline \& Kline 1992, Kishikawa et al. 1999, Méo et al. 2004, Tomashov-Matar et al. 2005, Zhang et al. 2005, Choi et al. 2013). We have previously shown that porcine oocyte activation using a combination of ionomycin (ION) and $\mathrm{Sr}^{2+}$ results in superior development of SCNT embryos compared with oocyte activation using ION alone (Che et al. 2007).

Currently, there is limited information available about the occurrence and consequences of DNA damage during embryo development as well as about the potential effects of the technologies used for embryo production on the occurrence of DNA damage. In somatic cells, the histone H2A.x has been shown to be indispensable for the preservation of genome integrity because it participates in the process of DNA doublestrand break (DSB) repair. H2A.x is a member of the $\mathrm{H} 2 \mathrm{~A}$ histone family including $\mathrm{H} 2 \mathrm{~A} 1, \mathrm{H} 2 \mathrm{~A} 2$, and $\mathrm{H} 2 \mathrm{AZ}$, which help in the package and organization of DNA into chromatin (West \& Bonner 1980). H2A.x is immediately activated by the phosphorylation of the $\mathrm{C}$-terminal serine residue 139 (Ser139) at the nascent sites of DSBs. This phosphorylation is mediated by one or more members of 
the PI3K-like kinase family, which includes ataxia telangiectasia mutated (ATM), ataxia telangiectasia and Rad3 related (ATR), and DNA-dependent protein kinase (DNA-PK) (Stiff et al. 2004, Takahashi \& Ohnishi 2005, Stiff et al. 2006). In 30 min of DSB formation, phosphorylated histone H2A.x (H2AX139ph) accumulates around the break sites creating foci where proteins involved in signaling and repair of DSBs begin to accumulate (Rogakou et al. 1999, Bonner et al. 2008). It has been demonstrated that only large $\mathrm{H} 2 \mathrm{AX} 139 \mathrm{ph}$ foci, i.e. those larger than $0.30 \mu \mathrm{m}^{3}$, indicate the sites of DSBs because they are tightly co-localized with DNA-damage signaling and repair proteins (Paull et al. 2000, McManus \& Hendzel 2005).

The presence of large H2AX139ph foci has been extensively used to evaluate the occurrence of DSBs in somatic cells (Bonner et al. 2008, Kinner et al. 2008, Jucha et al. 2010). There are also a few studies that have reported the presence of $\mathrm{H} 2 \mathrm{AX} 139 \mathrm{ph}$ foci in mouse and rat embryos (Forand et al. 2004, Luo et al. 2006, Adiga et al. 2007, Ziegler-Birling et al. 2009, Wossidlo et al. 2010, Grenier et al. 2012). Interestingly, DNA damage has been shown to impair cellular reprogramming and reduce the efficiency of production of induced pluripotent stem (iPS) cells (Marion et al. 2009). This suggests that genome integrity might be an important component affecting cell reprogramming and development of SCNT embryos. The objectives of this study were to i) investigate the occurrence of large H2AX139ph foci as indicators of DSBs during in vitro development of porcine embryos produced by IVF and SCNT; ii) evaluate the effect of the protocol used for oocyte activation on the occurrence of H2AX139ph foci in SCNT embryos; and iii) assess whether the presence of H2AX139ph foci is correlated with development and number of cells per embryo at cleavage and blastocyst stages.

\section{Materials and methods}

\section{Chemicals}

Unless otherwise indicated, all chemical reagents were purchased from Sigma Chemical Company (Sigma-Aldrich).

\section{Oocyte collection and in vitro maturation}

Ovaries of prepubertal gilts were obtained from a local abattoir (Olymel S.E.C./L.P., Saint-Esprit, QC, Canada) and transported to the laboratory in sterile $0.9 \% \mathrm{NaCl}$ at $30-35^{\circ} \mathrm{C}$. Follicles having a diameter of 3-6 $\mathrm{mm}$ were aspirated using an 18-gauge needle attached to a $10 \mathrm{ml}$ disposable syringe. Only cumulusoocyte complexes (COCs) surrounded by a minimum of three cumulus cell layers and having an evenly granulated cytoplasm were selected for in vitro maturation (IVM). Groups of 20 COCs were cultured in $0.1 \mathrm{ml}$ of maturation medium under mineral oil in a humidified atmosphere of $5 \% \mathrm{CO}_{2}$ and $95 \%$ air at $38.5^{\circ} \mathrm{C}$. The maturation medium consisted of TCM-199 (Life Technologies), supplemented with $20 \%$ porcine follicular fluid, $0.1 \mathrm{mg} / \mathrm{ml}$ cysteine, $10 \mathrm{ng} / \mathrm{ml}$ epidermal growth factor (Life
Technologies), $0.91 \mathrm{mM}$ sodium pyruvate, $3.05 \mathrm{mM}$ D-glucose, $0.5 \mu \mathrm{g} / \mathrm{ml}$ luteinizing hormone (LH) (SIOUX Biochemical, Inc., Sioux Center, IA, USA), $0.5 \mu \mathrm{g} / \mathrm{ml}$ follicle stimulating hormone (FSH) (SIOUX Biochemical, Inc.), and $20 \mu \mathrm{g} / \mathrm{ml}$ gentamicin (Life Technologies). After 22-24 h of maturation, oocytes were transferred to the same IVM medium, but without LH and FSH, for an additional $20-22 \mathrm{~h}$ under the same conditions. Cumulus cells were removed by vortex in TCM-199 HEPES-buffered medium (Life Technologies) supplemented with $0.1 \%$ of hyaluronidase, and then the oocytes were used for IVF or SCNT.

\section{IVF}

Matured oocytes were washed thrice with IVF medium (113.1 $\mathrm{mM} \mathrm{NaCl}, 3 \mathrm{mM} \mathrm{KCl}, 7.5 \mathrm{mM} \mathrm{CaCl} 2 \cdot 2 \mathrm{H}_{2} \mathrm{O}, 20 \mathrm{mM}$ Tris, $11 \mathrm{mM}$ glucose, $5 \mathrm{mM}$ sodium pyruvate, and $0.1 \% \mathrm{BSA}$; Abeydeera \& Day 1997). Groups of 20 oocytes were then placed in $90 \mu$ l drops of IVF medium covered with mineral oil. Spermatozoa were prepared from fresh semen samples of a proven fertile boar. The spermatozoa were washed twice with IVF medium by centrifugation $(800 \mathrm{~g}$ ) for $3 \mathrm{~min}$, and the sperm pellet was resuspended in IVF medium. Oocytes in each drop were fertilized by adding $10 \mu \mathrm{l}$ of the sperm preparation with the concentration adjusted to 10000 spermatozoa per oocyte. The oocytes were co-incubated with the sperm for $6 \mathrm{~h}$ and then collected, washed twice to remove unattached sperm cells and then cultured in PZM-3 medium (Yoshioka et al. 2002).

\section{Somatic cell nuclear transfer}

Cumulus-free oocytes selected with a polar body were cultured in TCM-199 medium supplemented with $0.4 \mu \mathrm{g} / \mathrm{ml}$ demecolcine and $0.05 \mathrm{M}$ sucrose for $60 \mathrm{~min}$. This treatment resulted in a protrusion in the ooplasmic membrane that contained the metaphase chromosomes (Yin et al. 2002). The oocytes were then transferred into Tyrode's lactate-pyruvate-HEPES medium (5 mM glucose, $113 \mathrm{mM} \mathrm{NaCl}, 3.2 \mathrm{mM} \mathrm{KCl}, 0.5 \mathrm{mM} \mathrm{MgCl}$, $0.4 \mathrm{mM} \mathrm{NaH} \mathrm{PO}_{4}, 2 \mathrm{mM} \mathrm{NaHCO}, 20 \mathrm{mM}$ lactate, $10 \mathrm{mM}$ HEPES, and $0.3 \%$ polyvinyl alcohol (PVA), pH 7.4) supplemented with $7.5 \mathrm{mg} / \mathrm{ml}$ cytochalasin B (CB) for 5-10 min and enucleated by removing the protruded oocyte chromatin together with the first polar body. A fetal fibroblast cell derived from a confluent culture was transferred into the perivitelline space of each enucleated oocyte and electrically fused using a single DC pulse of $1.6 \mathrm{kV} / \mathrm{cm}$ for $70 \mu \mathrm{s}$. Electrofusion was performed in a $0.28 \mathrm{M}$ mannitol solution supplemented with $50 \mu \mathrm{M} \mathrm{CaCl}_{2}, 100 \mu \mathrm{M}$ $\mathrm{MgSO}_{4}$, and $0.1 \%$ PVA. The reconstructed oocytes were cultured in TCM-199 medium supplemented with $3 \mathrm{mg} / \mathrm{ml} \mathrm{BSA}$ for $1 \mathrm{~h}$ before activation.

\section{Oocyte activation}

The reconstructed oocytes were activated using the following protocols (Che et al. 2007):

i) ION: the oocytes were exposed for 5 min to $15 \mu \mathrm{M} I O N$ in TCM-199 and then transferred to PZM-3 medium supplemented with $\mathrm{CB}(7.5 \mathrm{~g} / \mathrm{ml})$ and cycloheximide $(\mathrm{CHX} ; 10 \mathrm{~g} / \mathrm{ml})$ for $4 \mathrm{~h}$. 
ii) $\mathrm{ION}+\mathrm{Sr}^{2+}$ : the oocytes were exposed to $15 \mathrm{M}$ ION for $5 \mathrm{~min}$ and then transferred to $10 \mathrm{mM} \mathrm{Sr}^{2+}$ in PZM-3 $\left(\mathrm{Ca}^{2+}\right.$ free) $+7.5 \mathrm{~g} / \mathrm{ml}$ of $\mathrm{CB}$ and $10 \mathrm{~g} / \mathrm{ml}$ of $\mathrm{CHX}$ for $4 \mathrm{~h}$. After activation, the oocytes were washed and cultured in PZM-3 medium.

\section{Embryo culture}

The IVF or SCNT oocytes were washed thrice in PZM-3 medium supplemented with $3 \mathrm{mg} / \mathrm{ml}$ BSA (fatty acid free) and cultured in a humidified atmosphere of $5 \% \mathrm{CO}_{2}$ and $95 \%$ air at $38.5^{\circ} \mathrm{C}$. The cleavage rate was determined $48 \mathrm{~h}$ after IVF or activation. The cleaved embryos were transferred to a fresh drop of PZM-3 medium, and on day 5 of culture, $10 \%$ fetal bovine serum was added, and the embryos were maintained in culture until day 7 .

\section{Western blotting}

In vitro produced porcine embryos (65 blastocysts) and porcine fetal fibroblasts were lysed in Laemmli buffer (Bio-Rad) containing Phosphatase and Protease Inhibitor Cocktail (GBiosciences, St Louis, MO, USA). Total lysate was resolved and transferred onto nitrocellulose membranes (Bio-Rad). After blocking with $5 \%$ BSA in Tris-buffered saline with $0.1 \%$ Tween, the membranes were incubated overnight with anti-phosphoH2A.x (Ser139) mouse MAB (dilution 1:1000; Millipore, Billerica, MA, USA) or with anti- $\beta$-actin rabbit polyclonal primary antibodies (1:5000; Abcam, Inc., Toronto, ON, Canada). Subsequently, the membranes were incubated for $1 \mathrm{~h}$ with peroxidase-conjugated anti-mouse (1:3000) or antirabbit (1:10 000) secondary antibodies (Cell Signaling, Boston, MA, USA). The membranes were incubated for 2 min with reagents provided with the Immun-Star WesternC Chemiluminescent Kit, and images were captured using the ChemiDoc MP System (Bio-Rad).

\section{Immunofluorescence staining}

Samples of IVF and SCNT embryos at 1- and 2-4-cell stages and day 7 blastocysts were fixed for 15-20 min in 4\% paraformaldehyde and permeabilized in 1\% Triton X-100 in PBS for $30 \mathrm{~min}$ at $37^{\circ} \mathrm{C}$. The samples were incubated for $1 \mathrm{~h}$ at room temperature in a blocking solution (3\% BSA and $0.2 \%$ Tween 20 in PBS) and then maintained overnight in the presence of anti-phospho-H2A.x (ser 139) mouse monoclonal primary antibodies (Millipore) diluted $(1: 1000)$ in the blocking solution. The embryos were then washed thrice for 20 min each with the blocking solution and incubated for $1 \mathrm{~h}$ at room temperature $\left(24-26^{\circ} \mathrm{C}\right)$ in the presence of 1:1000 diluted anti-mouse IgG Cy3-conjugated secondary antibodies (Jackson ImmunoResearch Laboratories, Baltimore, PA, USA). After this period, DNA was stained by exposing the samples to $10 \mu \mathrm{g} / \mathrm{ml}$ of $4^{\prime}, 6-$ diamidino-2-phenylindole (Life technologies) in the blocking solution for $20 \mathrm{~min}$. The samples were then washed thrice (20 min each) with the blocking solution and mounted on microscope slides using a drop of Mowiol. The slides were kept in a dark box and examined by epifluorescence using a Nikon eclipse 80i microscope (Nikon). Images were captured at
$200 \times, 400 \times$, or $600 \times$ magnification using a Retiga $2000 R$ monochrome digital camera (Qimaging, BC, Canada) and the SimplePCI Imaging Software (Compix, Inc., Sewickley, PA, USA). Nuclei were individually evaluated, and H2AX139ph foci larger than $0.30 \mu \mathrm{m}^{3}$, which indicates the sites of DNA DSBs (McManus \& Hendzel 2005, Grenier et al. 2012), were counted. The number of H2AX139ph foci was determined in IVF embryos at the pronuclear stage (at 10, 15, and $20 \mathrm{~h}$ post-fertilization (hpf)), SCNT embryos at $20 \mathrm{~h}$ post-nuclear transfer (hpnt), and both IVF and SCNT cleaved embryos (2- and 4-cell stages) and day 7 blastocysts at $48 \mathrm{~h}$. The results are presented as average number of $\mathrm{H} 2 \mathrm{AX} 139 \mathrm{ph}$ foci per nucleus or the proportion of nuclei with $<10$ foci, $\geq 10$ foci, and total positives.

\section{Statistical analyses}

All analyses were performed using the JMP Software (SAS Institute, Inc., Cary, NC, USA). Continuous data were analyzed using ANOVA, and the means were compared using Student's t-test or Tukey-Kramer Honestly Significant Difference (HSD) test for single or multiple comparisons respectively. Data were tested for normal distribution using the Shapiro-Wilk test and normalized when necessary. The correlations were done using simple linear regression analyses, and the nominal data were analyzed using the $\chi^{2}$ test. Differences were considered to be statistically significant at the $95 \%$ level $(P<0.05)$.

\section{Results}

\section{Presence of H2AX139ph in IVF embryos}

The specificity of $\mathrm{H} 2 \mathrm{AX} 139 \mathrm{ph}$ antibody was confirmed by western blotting using porcine fetal fibroblasts and porcine embryos on day 7 of in vitro development. A unique protein band of the expected molecular weight $(17 \mathrm{kDa})$ was detected in samples from both fibroblast cells and blastocysts (Fig. 1A).

The presence of $\mathrm{H} 2 \mathrm{AX} 139 \mathrm{ph}$ foci was first determined by immunofluorescence in IVF embryos at different stages of in vitro development. H2AX139ph was detected in pronuclei with an average of 9.2 foci per pronucleus (Fig. 1B). The average number of foci was numerically higher but not statistically significant in zygotes fixed at 15 and $20 \mathrm{~h}$ compared with those fixed at $10 \mathrm{hpf}$ $(P=0.096$; Fig. 1C). H2AX139ph foci were found in most of the zygotes regardless of the time they were fixed after fertilization (Fig. 1D). Based on the average number of foci counted per pronucleus (approximately ten), we decided to classify H2AX139ph-positive nuclei as those with less than and more than ten foci. The proportion of pronuclei with $<10$ foci compared with that of pronuclei with $\geq 10$ foci was not significantly different in zygotes fixed at 10, 15, and $20 \mathrm{hpf}$ (Fig. 1D).

Cleaved embryos fixed at $48 \mathrm{hpf}$ were grouped into 2-cell-stage embryos (slow cleaving) and 4-cell-stage embryos (fast cleaving). The mean number of H2AX139ph foci per nucleus (Fig. 2A) was higher 


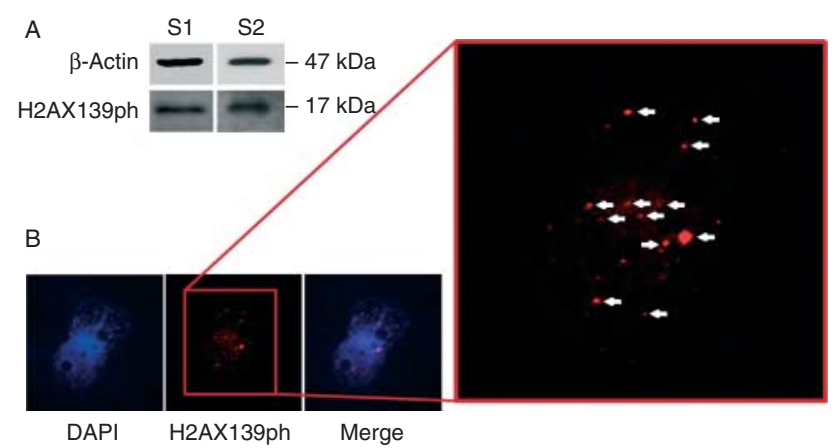

nuclei with $<10$ foci or $\geq 10$ foci, was not statistically different between the groups activated with ION and $\mathrm{ION}+\mathrm{Sr}^{2+}$ (Fig. 4).

In cleaved embryos fixed at $48 \mathrm{hpnt}$, the presence of H2AX139ph foci was affected by both the number of cells (two vs four cells) and the activation protocol (Fig. 5). The proportion of nuclei with less than ten foci was higher in the 4-cell-stage embryos (38.8\%) than in the 2-cell-stage embryos $(10.5 \%)$ that were activated with ION. There was no significant difference between the 2- and 4-cell-stage embryos in the group activated with $\mathrm{ION}+\mathrm{Sr}^{2+}$ (Fig. 5A). The proportion of nuclei with $\geq 10$ foci was higher in the 2-cell-stage embryos $(42.1$ and $35.2 \%)$ than in the 4-cell-stage embryos $(11.1$ and $8 \%)$ that were activated with either ION or $\mathrm{ION}+\mathrm{Sr}^{2+}$ respectively (Fig. 5B). Within the same cell stage, the activation protocol had a significant effect on

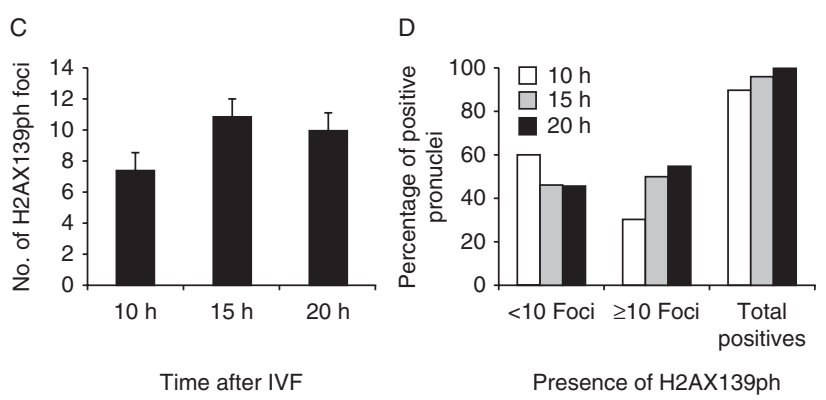

Figure 1 (A) Immunoblots showing protein bands for H2AX139ph and $\beta$-actin in porcine fetal fibroblasts (S1) and day 7 porcine embryos (S2). (B) Representative fluorescent images showing the presence of $\mathrm{H} 2 \mathrm{AX} 139 \mathrm{ph}$ foci (red) in the pronuclei (blue) of a porcine zygote fixed $20 \mathrm{~h}$ after IVF. Arrows indicate H2AX139ph foci larger than $0.30 \mu \mathrm{m}^{3}$. (C) Mean number of $\mathrm{H} 2 \mathrm{AX} 139 \mathrm{ph}$ foci in the pronuclei of porcine zygotes fixed 10, 15, and $20 \mathrm{~h}$ after IVF. (D) Percentage of zygotes with H2AX139ph foci ( $<10$ foci, $\geq 10$ foci, and total positives) 10,15 , and $20 \mathrm{~h}$ after IVF. Results shown in (C) and (D) were not significantly different $(P>0.05)$.

$(P=0.011)$ in embryos with two cells $(16.7$ foci) than in those with four cells (6.0 foci; Fig. 2B). H2AX139ph foci were detected in most of the nuclei of both the 2- and 4-cell-stage embryos (Fig. 2C). The proportion of nuclei presenting more than ten foci was also higher $(P=0.043)$ in embryos with two cells (46.4\%) than in those with four cells $(21.8 \%$; Fig. 2C). Embryos with four cells had a higher proportion of nuclei with $<10$ foci than those with $\geq 10$ foci (Fig. 2C).

In day 7 blastocysts produced by IVF (Fig. 3A), H2AX139ph was detected in $49.8 \%$ of the nuclei, whereas $36.6 \%$ of the positive cells had $<10$ foci and $13.1 \%$ had $\geq 10$ foci $(P<0.001$; Fig. 3B). Interestingly, there was a negative correlation $\left(r^{2}=0.6834\right.$; $P<0.001)$ between the percentage of cells with $\mathrm{H} 2 \mathrm{AX} 139 \mathrm{ph}$ foci and the total number of cells per blastocyst (Fig. 3C).

\section{Presence of H2AX139ph in SCNT embryos}

This experiment evaluated the presence of H2AX139ph foci in SCNT embryos produced with different activation protocols (ION vs $\mathrm{ION}+\mathrm{Sr}^{2+}$ ). In the 1 -cell-stage embryos fixed at $20 \mathrm{hpnt}$, the proportion of nuclei presenting $\mathrm{H} 2 \mathrm{AX} 139 \mathrm{ph}$ foci, as well as the proportion of

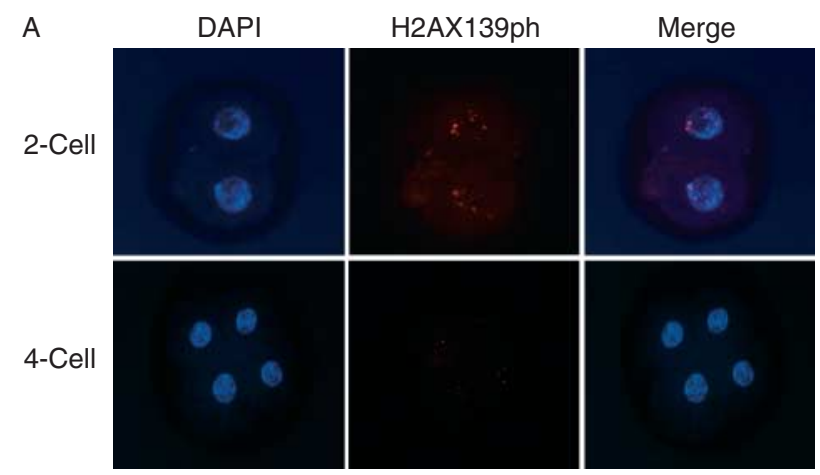

B
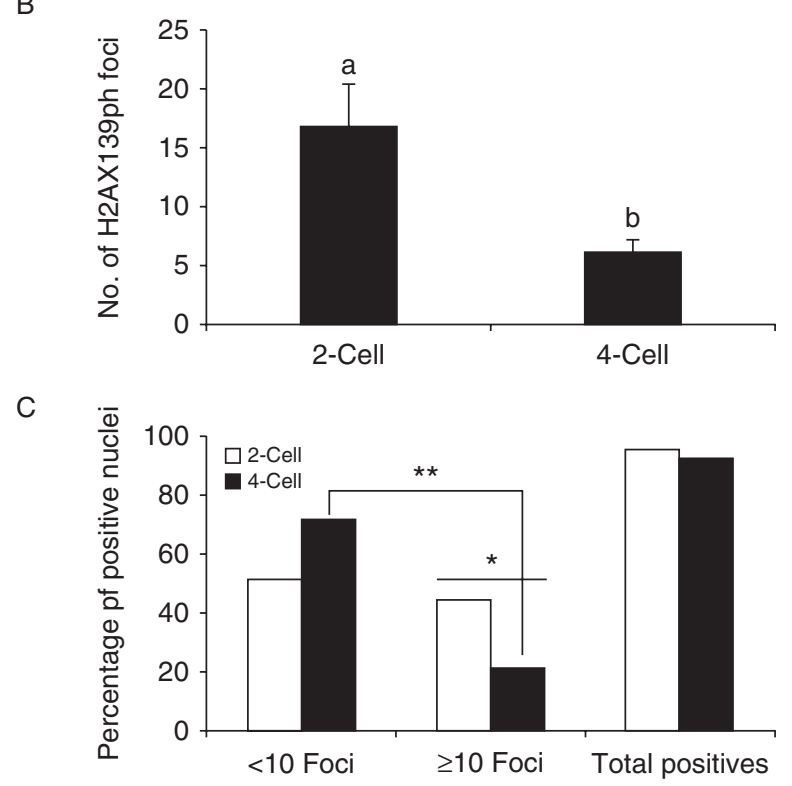

Figure 2 Presence of $\mathrm{H} 2 \mathrm{AX} 139 \mathrm{ph}$ foci in cleaved embryos fixed $48 \mathrm{~h}$ after IVF. (A) Representative fluorescent images showing the presence of $\mathrm{H} 2 \mathrm{AX} 139 \mathrm{ph}$ foci in the 2- and 4-cell-stage embryos. (B) Mean number of $\mathrm{H} 2 \mathrm{AX} 139 \mathrm{ph}$ foci in the 2- and 4-cell-stage embryos (a vs b, $P=0.011)$. (C) Percentage of nuclei with H2AX139ph foci $(<10$ foci, $\geq 10$ foci, and total positives) from the total number of evaluated nuclei. ${ }^{*} P=0.043$ and ${ }^{*} * P=0.004$. 
A
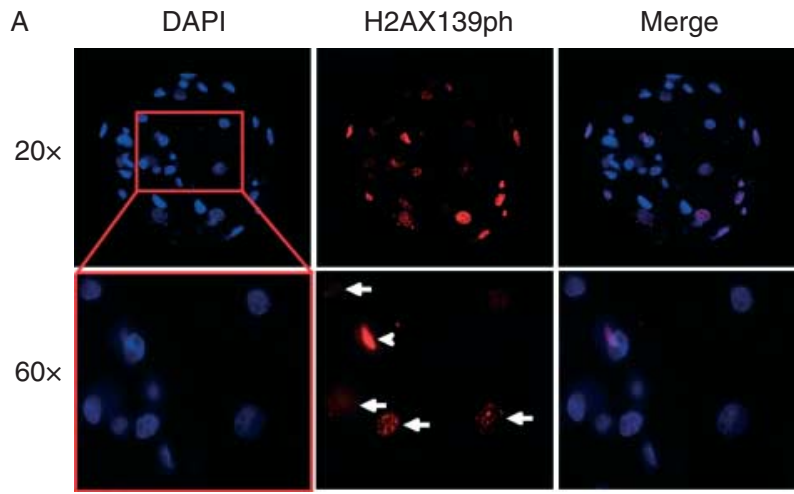

B

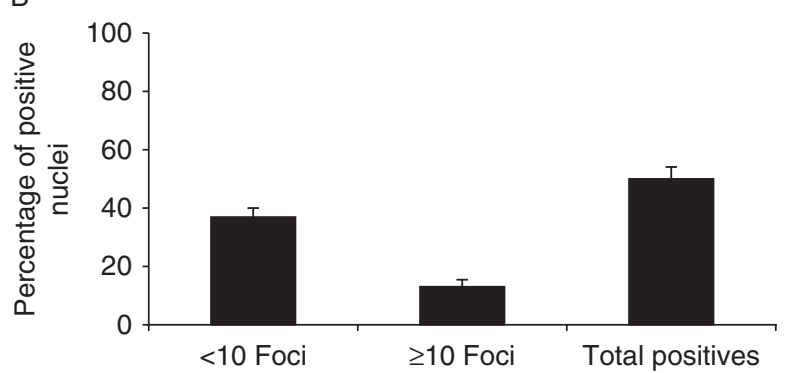

C

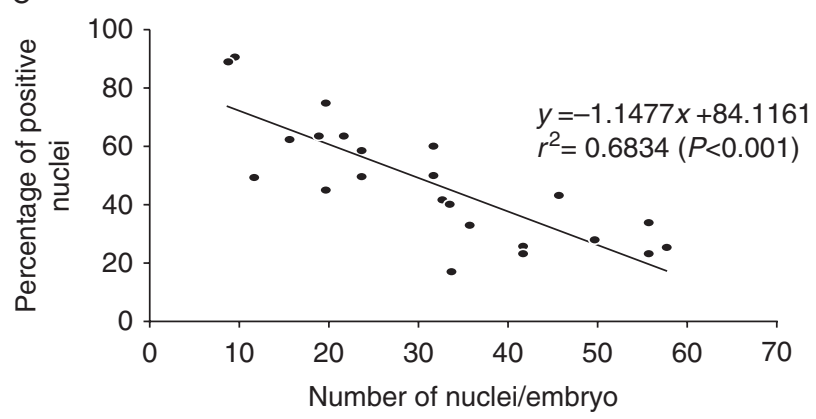

Figure 3 Presence of H2AX139ph in blastocysts on day 7 after IVF. (A) Representative fluorescent image of a day 7 blastocyst produced by IVF. Cell nuclei are stained in blue and H2AX139ph foci in red. Arrows indicate the presence of $\mathrm{H} 2 \mathrm{AX} 139 \mathrm{ph}$ foci in nuclei ( $\geq 10$ foci and $<10$ foci) and the arrowhead indicates a nucleus in $M$ phase with diffuse $\mathrm{H} 2 \mathrm{AX} 139$ ph staining but absence of $\mathrm{H} 2 \mathrm{AX} 139$ ph foci.

(B) Percentage of nuclei with H2AX139ph foci ( $<10$ foci, $\geq 10$ foci, and total positives) from the total number of evaluated nuclei. $(P<0.05)$ between the groups. (C) Correlation between the percentage of $\mathrm{H} 2 \mathrm{AX} 139$ ph-positive nuclei and the total number of nuclei in day 7 blastocysts $(P<0.001)$.

the proportion of nuclei presenting H2AX139ph foci. The proportion of nuclei with more than ten foci (38.8 vs $16 \%$; Fig. $5 \mathrm{~A}$ ) and the total number of H2AX139phpositive nuclei (50 vs $24 \%$; Fig. 5C) were significantly higher in the 4-cell-stage embryos activated with ION than in those activated with $\mathrm{ION}+\mathrm{Sr}^{2+}$.

In blastocysts produced by SCNT, the percentage of nuclei with $<10 \mathrm{H} 2 \mathrm{AX} 139 \mathrm{ph}$ foci $(27.2 \mathrm{vs} 12.0 \%)$ and the total number of H2AX139ph-positive nuclei (43.7 and $20.7 \%$ ) were significantly higher in SCNT blastocysts produced with the ION activation protocol than in those produced with the ION $+\mathrm{Sr}^{2+}$ activation protocol (Fig. 6A). There was a negative correlation $\left(r^{2}=0.6284\right.$; $P<0.001)$ between the percentage of cells with H2AX139ph foci and the total number of cells in SCNT blastocysts (Fig. 6B).

\section{Discussion}

The phosphorylation of histone H2A.x is essential to promote DNA DSB repair by acting as a platform for the accumulation and retention of important proteins involved in signaling and repair mechanisms (Kinner et al. 2008). Despite its importance in DSB repair, $\mathrm{H} 2 \mathrm{AX} 139 \mathrm{ph}$ has not been thoroughly investigated during early-embryo development. Few reports have shown the presence of $\mathrm{H} 2 \mathrm{AX} 139$ ph during embryo development in mice (Luo et al. 2006, Adiga et al. 2007, Pacchierotti et al. 2011, Xiao et al. 2012) and rats (Barton et al. 2007, Grenier et al. 2012), but whether the occurrence of H2AX139ph is correlated with embryo development and quality has not been investigated. Moreover, there were no studies conducted to investigate whether the technologies used for in vitro embryo production affect the occurrence of $\mathrm{H} 2 \mathrm{AX} 139 \mathrm{ph}$. Therefore, this study used porcine embryos to investigate the occurrence of $\mathrm{H} 2 \mathrm{AX} 139 \mathrm{ph}$ during in vitro development of embryos produced by IVF and SCNT. Based on the presence of $\mathrm{H} 2 \mathrm{AX} 139 \mathrm{ph}$ foci as an indicator of DSBs, the main findings of this study were as follows: i) DSBs are detected during all stages of in vitro embryo development; ii) fast-developing embryos at $48 \mathrm{~h}$ (four cells) have fewer DSBs than slow-developing embryos (two cells); iii) the oocyte activation protocol affects the occurrence of DSBs in embryos produced by SCNT; and iv) better-quality blastocysts with a higher cell number have fewer DSBs than low-quality blastocysts.

It has been shown that H2AX139ph foci larger than $0.30 \mu \mathrm{m}^{3}$ indicate the sites of DNA DSBs and co-localize

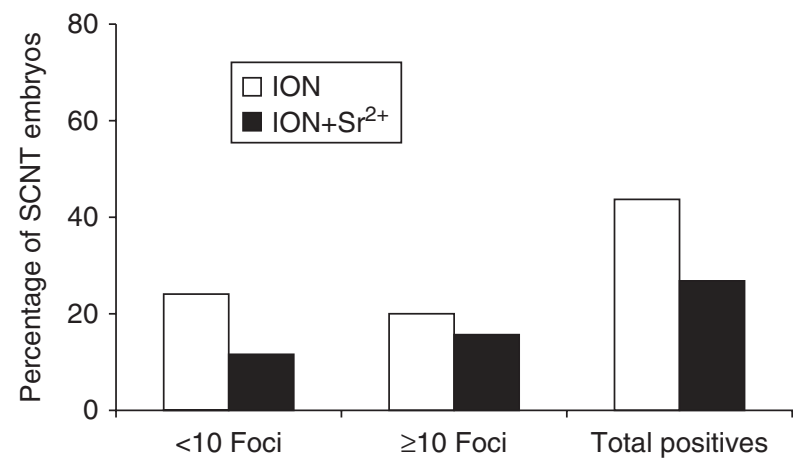

Figure 4 Presence of H2AX139ph in 1-cell-stage SCNT embryos fixed $20 \mathrm{~h}$ after cell fusion. Bars represent the proportion of H2AX139phpositive embryos presenting $<10$ foci, $\geq 10$ foci, and total positives from the total number of evaluated nuclei. White and black bars represent embryos activated with $\mathrm{ION}$ and $\mathrm{ION}+\mathrm{Sr}^{2+}$ respectively. Differences between the ION and $\mathrm{ION}+\mathrm{Sr}^{2+}$ groups were not statistically significant $(P>0.05)$. 

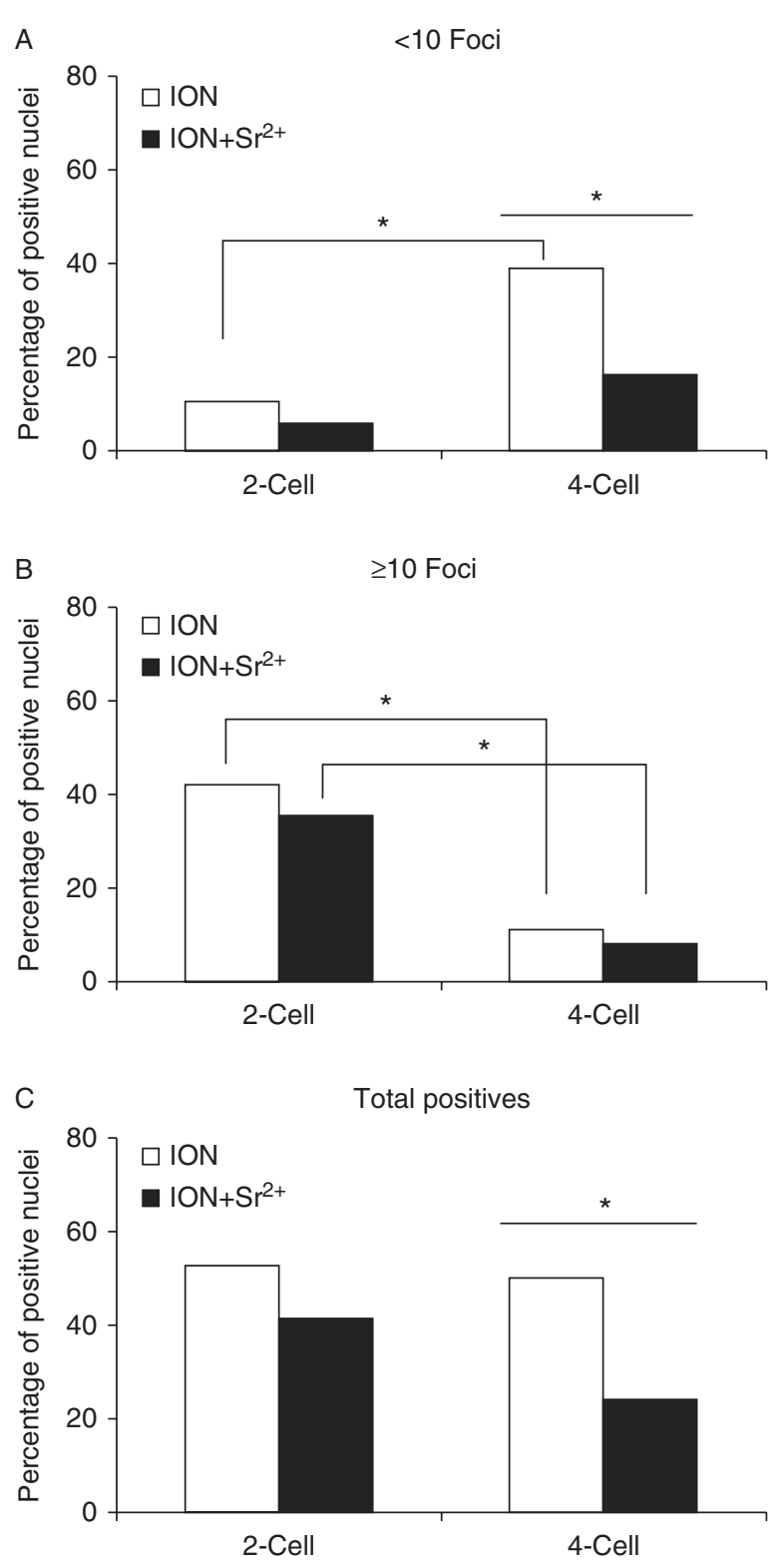

Figure 5 Effect of the activation protocol on the occurrence of $\mathrm{H} 2 \mathrm{AX} 139 \mathrm{ph}$ in SCNT embryos fixed $48 \mathrm{~h}$ after reconstruction. Percentage of H2AX139ph-positive nuclei with $<10$ foci (A), $\geq 10$ foci (B), and total positives (C) from the total number of evaluated nuclei in the 2- and 4-cell-stage embryos. White and black bars represent embryos activated with $\mathrm{ION}$ and $\mathrm{ION}+\mathrm{Sr}^{2+}$ respectively. Asterisks indicate significant differences $(P<0.05)$ between the groups.

with DNA-repair proteins including RAD51, BRCA1, 53BP1, NBS1, MRE11A, KU80, XRCC4, and DNA ligase IV (Paull et al. 2000, McManus \& Hendzel 2005). In this study, we observed the presence of large H2AX139ph foci in a high proportion of nuclei in porcine embryos evaluated on day 1 (pronuclear stage), day 2 (2- and 4-cell stages), and day 7 (blastocyst stage) of in vitro culture. This suggests that porcine embryos might rely on $\mathrm{H} 2 \mathrm{AX} 139$ ph to promote DNA-damage repair during all stages of development from the zygote to the blastocyst stage. Although $\mathrm{H} 2 \mathrm{AX} 139$ ph foci have also been reported to be present in zygotes and cleaved embryos in rats (Barton et al. 2007, Grenier et al. 2012), there are probably differences among species since H2AX139ph foci have been detected in cleaved embryos but not in the zygotes of mice (Adiga et al. 2007, Yukawa et al. 2007).

This study revealed that cultured porcine embryos have a high incidence of DSBs, which can probably compromise cell cycle progression and embryo development and quality. Supporting this hypothesis are our findings showing that at $48 \mathrm{~h}$ of development the number of H2AX139ph foci was higher in the 2-cell-stage embryos than in the 4-cell-stage embryos. Moreover, we observed a higher proportion of nuclei with $\geq 10$ foci in the 2-cell-stage embryos than in the 4-cell-stage embryos. It has been shown that fast-cleaving porcine embryos produce more and better-quality blastocysts than slow-cleaving embryos (Dang-Nguyen et al. 2010, Coutinho et al. 2011). Similarly, fast-developing porcine
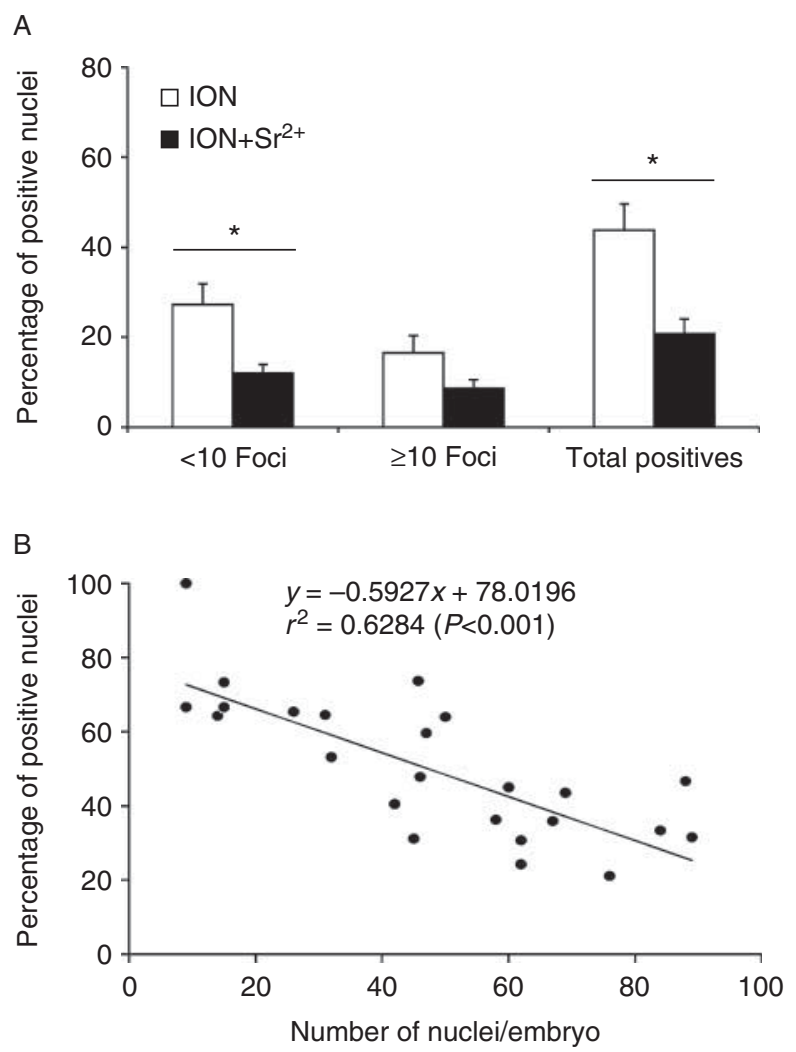

Figure 6 Presence of $\mathrm{H} 2 \mathrm{AX} 139 \mathrm{ph}$ foci and correlation between embryo cell number and presence of H2AX139ph in SCNT blastocysts produced with different activation protocols. (A) Percentage of nuclei with $\mathrm{H} 2 \mathrm{AX} 139 \mathrm{ph}$ foci ( $<10$ foci, $\geq 10$ foci, and total positives) from the total number of evaluated nuclei in SCNT blastocysts fixed on day 7. White and black bars represent embryos activated with ION and $\mathrm{ION}+\mathrm{Sr}^{2+}$ respectively. Asterisks indicate significant differences $(P<0.05)$ between the ION and ION $+\mathrm{Sr}^{2+}$ groups. (B) Correlation between the percentage of $\mathrm{H} 2 \mathrm{AX} 139 \mathrm{ph}$-positive nuclei and the total number of nuclei in day 7 SCNT blastocysts $(P<0.001)$. 
embryos produced by SCNT have a higher potential to support embryo development than slow-developing embryos (Isom et al. 2012). Therefore, based on current observations, it appears that a higher incidence of DSBs delays early-embryo cleavages and compromises laterembryo development and quality.

Our findings based on blastocysts, produced both by IVF and SCNT, revealed a negative correlation between the percentage of cells presenting H2AX139ph foci and the total number of cells per embryo. This suggests that the occurrence of DSBs is an important determinant of blastocyst quality. It has been shown that the preimplantation-stage embryos have the capacity to respond to DSBs by activating genes that control DNA-damage repair mechanisms (Zheng et al. 2005, Henrique Barreta et al. 2012). The DNA-damage response involves cell cycle coordination and arrest at G1/S or G2/M checkpoints to allow DNA-damage repair before DNA replication and cell division (Aquilina et al. 1999). This gives more time for the affected cells to repair DNA damage (Finkielstein et al. 2001), but in some cases it can lead to the activation of apoptotic pathways (Zhivotovsky \& Kroemer 2004, Cook et al. 2009). Our observation that embryos with a higher proportion of H2AX139ph-positive cells have a lower cell number suggests that the checkpoint pathways are also induced in porcine embryos to repair/preserve genome integrity. The overall findings of this study were very similar for embryos produced by IVF and SCNT, which further supports an important effect of DSBs during in vitro embryo development.

This study provides evidence that the occurrence of DSBs may represent an important component impairing the development and efficiency of embryo production by SCNT. In somatic cells, DNA damage has been shown to reduce efficiency in the production of iPS cells (Marion et al. 2009). Moreover, H2AX139ph has been shown to be important for maintaining self-renewal of mouse embryonic and iPS cells (Turinetto et al. 2012). Thus, in addition to affecting embryo development, one can speculate that DNA damage and/or presence of H2AX139ph may also play a role in cell reprogramming in SCNT embryos. However, this requires further investigation.

Previous studies have shown that activation of oocytes with ION $+\mathrm{Sr}^{2+}$ result in superior development of SCNT porcine embryos compared with activation with ION alone (Che et al. 2007). One possibility is that $\mathrm{Sr}^{2+}$ treatment promotes a higher physiological response in the oocytes and consequently reduces the detrimental effects of cell cycle incompatibilities between the transferred nucleus and the host cytoplasm. Abnormal cell cycle compatibilities are thought to affect chromatin replication, integrity, and segregation in SCNT embryos (Campbell 1999). In this study, we investigated whether $\mathrm{Sr}^{2+}$ treatment affected the occurrence of DSBs in SCNT embryos. Interestingly, $\mathrm{Sr}^{2+}$ reduced the percentage of nuclei with less than ten $\mathrm{H} 2 \mathrm{AX} 139 \mathrm{ph}$ foci and the total number of positive nuclei in the 4-cell-stage embryos. Moreover, the proportion of nuclei with H2AX139ph foci at the blastocyst stage was also reduced in the group activated with $\mathrm{ION}+\mathrm{Sr}^{2+}$. These observations demonstrate that better rates of embryo production from oocytes activated by $\mathrm{Sr}^{2+}$ can be a consequence of a reduction in the occurrence of DSBs in the developing embryo.

In summary, this study has for the first time, to our knowledge, characterized the presence of H2AX139ph during in vitro development of porcine embryos produced by IVF and SCNT. Based on the presence of H2AX139ph foci, we confirmed that DSBs occur during all stages of culture from zygote to the blastocyst stage. We also observed that fast-developing embryos have fewer DSBs than slow-developing embryos, as well as the existence of a negative correlation between the number of cells with DSBs and the total number of cells in the blastocyst-stage embryos. Moreover, we provide evidence that the activation protocol influences the occurrence of DSBs in the cleavage-stage embryos produced by SCNT. Together, these observations suggest that the presence of H2AX139ph foci is a good indicator of embryo quality, which could be used as a marker for developing improved protocols for in vitro embryo production.

\section{Declaration of interest}

The authors declare that there is no conflict of interest that could be perceived as prejudicing the impartiality of the research reported.

\section{Funding}

R C Bohrer was supported by a scholarship from the Science Without Borders Program of the Brazilian Council of Scientific and Technological Development (CNPq).

\section{Acknowledgements}

The authors thank Olymel S.E.C./L.P. for the donation of porcine ovaries. This study was supported by the Natural Sciences and Engineering Research Council (NSERC) of Canada.

\section{References}

Abeydeera LR \& Day BN 1997 Fertilization and subsequent development in vitro of pig oocytes inseminated in a modified Tris-buffered medium with frozen-thawed ejaculated spermatozoa. Biology of Reproduction 57 729-734. (doi:10.1095/biolreprod57.4.729)

Abeydeera LR, Wang WH, Cantley TC, Rieke A, Murphy CN, Prather RS \& Day BN 2000 Development and viability of pig oocytes matured in a protein-free medium containing epidermal growth factor. Theriogenology 54 787-797. (doi:10.1016/S0093-691X(00)00390-3)

Adiga SK, Toyoshima M, Shimura T, Takeda J, Uematsu N \& Niwa O 2007 Delayed and stage specific phosphorylation of $\mathrm{H} 2 \mathrm{AX}$ during preimplantation development of $\gamma$-irradiated mouse embryos. Reproduction 133 415-422. (doi:10.1530/REP-06-0048) 
Aigner B, Renner S, Kessler B, Klymiuk N, Kurome M, Wünsch A \& Wolf E 2010 Transgenic pigs as models for translational biomedical research. Journal of Molecular Medicine 88 653-664. (doi:10.1007/s00109010-0610-9)

Aquilina G, Crescenzi M \& Bignami M 1999 Mismatch repair, G2/M cell cycle arrest and lethality after DNA damage. Carcinogenesis 20 2317-2326. (doi:10.1093/carcin/20.12.2317)

Barton TS, Robaire B \& Hales BF 2007 DNA damage recognition in the rat zygote following chronic paternal cyclophosphamide exposure. Toxicological Sciences 100 495-503. (doi:10.1093/toxsci/kfm242)

Bonner WM, Redon CE, Dickey JS, Nakamura AJ, Sedelnikova OA, Solier S \& Pommier Y $2008 \gamma \mathrm{H} 2 \mathrm{AX}$ and cancer. Nature Reviews. Cancer 8 957-967. (doi:10.1038/nrc2523)

Bortvin A, Eggan K, Skaletsky H, Akutsu H, Berry DL, Yanagimachi R, Page DC \& Jaenisch R 2003 Incomplete reactivation of Oct4-related genes in mouse embryos cloned from somatic nuclei. Development 130 1673-1680. (doi:10.1242/dev.00366)

Campbell KH 1999 Nuclear equivalence, nuclear transfer, and the cell cycle. Cloning 1 3-15. (doi:10.1089/15204559950020058)

Che L, Lalonde A \& Bordignon V 2007 Chemical activation of parthenogenetic and nuclear transfer porcine oocytes using ionomycin and strontium chloride. Theriogenology 67 1297-1304. (doi:10.1016/ j.theriogenology.2007.02.006)

Choi I, Zhu J \& Campbell KH 2013 The combined treatment of calcium ionophore with strontium improves the quality of ovine SCNT embryo development. Zygote 21 139-150. (doi:10.1017/S096719941 2000470)

Cook PJ, Ju BG, Telese F, Wang X, Glass CK \& Rosenfeld MG 2009 Tyrosine dephosphorylation of $\mathrm{H} 2 \mathrm{AX}$ modulates apoptosis and survival decisions. Nature 458 591-596. (doi:10.1038/nature07849)

Coutinho ARS, Assumpção MEO \& Bordignon V 2011 Presence of cleaved caspase 3 in swine embryos of different developmental capacities produced by parthenogenetic activation. Molecular Reproduction and Development 78 673-683. (doi:10.1002/mrd.21368)

Dang-Nguyen TQ, Kikuchi K, Somfai T, Ozawa M, Nakai M, Maedomari N, Viet-Linh N, Kanai Y, Nguyen BX \& Nagai T 2010 Evaluation of developmental competence of in vitro-produced porcine embryos based on the timing, pattern and evenness of the first cleavage and onset of the second cleavage. Journal of Reproduction and Development $\mathbf{5 6}$ 593-600. (doi:10.1262/jrd.10-038M)

Finkielstein CV, Lewellyn AL \& Maller JL 2001 The midblastula transition in Xenopus embryos activates multiple pathways to prevent apoptosis in response to DNA damage. PNAS 98 1006-1011. (doi:10.1073/pnas.98. 3.1006)

Fissore RA, Dobrinsky JR, Balise JJ, Duby RT \& Robl JM 1992 Patterns of intracellular $\mathrm{Ca}^{2+}$ concentrations in fertilized bovine eggs. Biology of Reproduction 47 960-969. (doi:10.1095/biolreprod47.6.960)

Forand A, Dutrillaux B \& Bernardino-Sgherri J $2004 \gamma-\mathrm{H} 2 \mathrm{AX}$ expression pattern in non-irradiated neonatal mouse germ cells and after low-dose $\gamma$-radiation: relationships between chromatid breaks and DNA doublestrand breaks. Biology of Reproduction 71 643-649. (doi:10.1095/ biolreprod.104.027466)

Fulka J \& Fulka H 2007 Somatic cell nuclear transfer (SCNT) in mammals. In Somatic Cell Nuclear Transfer, pp 93-102. Ed. P Sutovsky. New York: Springer.

Grenier L, Robaire B \& Hales BF 2012 The activation of DNA damage detection and repair responses in cleavage-stage rat embryos by a damaged paternal genome. Toxicological Sciences 127 555-566. (doi:10.1093/toxsci/kfs120)

Henrique Barreta M, Garziera Gasperin B, Braga Rissi V, de Cesaro MP, Ferreira R, de Oliveira JF, Gonçalves PB \& Bordignon V 2012 Homologous recombination and non-homologous end-joining repair pathways in bovine embryos with different developmental competence. Experimental Cell Research 318 2049-2058. (doi:10.1016/j.yexcr.2012. 06.003)

Isom SC, Li RF, Whitworth KM \& Prather RS 2012 Timing of first embryonic cleavage is a positive indicator of the in vitro developmental potential of porcine embryos derived from in vitro fertilization, somatic cell nuclear transfer and parthenogenesis. Molecular Reproduction and Development 79 197-207. (doi:10.1002/mrd.22013)

Jucha A, Wegierek-Ciuk A, Koza Z, Lisowska H, Wojcik A, Wojewodzka M \& Lankoff A 2010 FociCounter: a freely available PC programme for quantitative and qualitative analysis of $\gamma-\mathrm{H} 2 \mathrm{AX}$ foci. Mutation Research/Genetic Toxicology and Environmental Mutagenesis 696 16-20. (doi:10.1016/j.mrgentox.2009.12.004)

Kinner A, Wu W, Staudt C \& Iliakis G $2008 \gamma-\mathrm{H} 2 \mathrm{AX}$ in recognition and signaling of DNA double-strand breaks in the context of chromatin. Nucleic Acids Research 36 5678-5694. (doi:10.1093/nar/gkn550)

Kishikawa H, Wakayama T \& Yanagimachi R 1999 Comparison of oocyteactivating agents for mouse cloning. Cloning $\mathbf{1} 153-159$. (doi:10.1089/ 15204559950019915)

Kline D \& Kline JT 1992 Repetitive calcium transients and the role of calcium in exocytosis and cell cycle activation in the mouse egg. Developmental Biology 149 80-89. (doi:10.1016/0012-1606(92)90265-I)

Kues WA \& Niemann H 2004 The contribution of farm animals to human health. Trends in Biotechnology 22 286-294. (doi:10.1016/j.tibtech. 2004.04.003)

Kuwaki K, Tseng YL, Dor FJ, Shimizu A, Houser SL, Sanderson TM, Lancos CJ, Prabharasuth DD, Cheng J, Moran K et al. 2005 Heart transplantation in baboons using $\alpha 1,3$-galactosyltransferase gene-knockout pigs as donors: initial experience. Nature Medicine 11 29-31. (doi:10.1038/nm1171)

Lucifero D, Suzuki J, Bordignon V, Martel J, Vigneault C, Therrien J, Filion F, Smith LC \& Trasler JM 2006 Bovine SNRPN methylation imprint in oocytes and day 17 in vitro-produced and somatic cell nuclear transfer embryos. Biology of Reproduction 75 531-538. (doi:10.1095/biolreprod.106.051722)

Luo Q, Yang J, Zeng Q-L, Zhu X-M, Qian Y-L \& Huang H-F 2006 50-Hertz electromagnetic fields induce $\gamma \mathrm{H} 2 \mathrm{AX}$ foci formation in mouse preimplantation embryos in vitro. Biology of Reproduction 75 673-680. (doi:10.1095/biolreprod.106.052241)

Marion RM, Strati K, Li H, Murga M, Blanco R, Ortega S, FernandezCapetillo O, Serrano M \& Blasco MA 2009 A p53-mediated DNA damage response limits reprogramming to ensure iPS cell genomic integrity. Nature 460 1149-1153. (doi:10.1038/nature08287)

McManus KJ \& Hendzel MJ 2005 ATM-dependent DNA damageindependent mitotic phosphorylation of $\mathrm{H} 2 \mathrm{AX}$ in normally growing mammalian cells. Molecular Biology of the Cell 16 5013-5025. (doi:10.1091/mbc.E05-01-0065)

Méo SC, Leal CLV \& Garcia JM 2004 Activation and early parthenogenesis of bovine oocytes treated with ethanol and strontium. Animal Reproduction Science 81 35-46. (doi:10.1016/j.anireprosci.2003.09. 004)

Nascimento AB, Albornoz MS, Che L, Visintin JA \& Bordignon V 2010 Synergistic effect of porcine follicular fluid and dibutyryl cyclic adenosine monophosphate on development of parthenogenetically activated oocytes from pre-pubertal gilts. Reproduction in Domestic Animals 45 851-859. (doi:10.1111/j.1439-0531.2009.01368.x)

Niemann H, Tian XC, King WA \& Lee RS 2008 Epigenetic reprogramming in embryonic and foetal development upon somatic cell nuclear transfer cloning. Reproduction 135 151-163. (doi:10.1530/REP-07-0397)

Pacchierotti F, Ranaldi R, Derijck AA, van der Heijden GW \& de Boer $P$ 2011 In vivo repair of DNA damage induced by X-rays in the early stages of mouse fertilization, and the influence of maternal PARP1 ablation. Mutation Research 714 44-52. (doi:10.1016/j.mrfmmm.2011. 06.010)

Paull TT, Rogakou EP, Yamazaki V, Kirchgessner CU, Gellert M \& Bonner WM 2000 A critical role for histone H2AX in recruitment of repair factors to nuclear foci after DNA damage. Current Biology 10 886-895. (doi:10.1016/S0960-9822(00)00610-2)

Rogakou EP, Boon C, Redon C \& Bonner WM 1999 Megabase chromatin domains involved in DNA double-strand breaks in vivo. Journal of Cell Biology 146 905-916. (doi:10.1083/jcb.146.5.905)

Stiff T, O'Driscoll M, Rief N, Iwabuchi K, Löbrich M \& Jeggo PA 2004 ATM and DNA-PK function redundantly to phosphorylate $\mathrm{H} 2 \mathrm{AX}$ after exposure to ionizing radiation. Cancer Research 64 2390-2396. (doi:10.1158/0008-5472.CAN-03-3207)

Stiff T, Walker SA, Cerosaletti K, Goodarzi AA, Petermann E, Concannon P, O'Driscoll M \& Jeggo PA 2006 ATR-dependent phosphorylation and activation of ATM in response to UV treatment or replication fork stalling. EMBO Journal 25 5775-5782. (doi:10.1038/sj.emboj.7601446)

Takahashi A \& Ohnishi T 2005 Does $\gamma \mathrm{H} 2 \mathrm{AX}$ foci formation depend on the presence of DNA double strand breaks? Cancer Letters 229 171-179. (doi:10.1016/j.canlet.2005.07.016) 
Tomashov-Matar R, Tchetchik D, Eldar A, Kaplan-Kraicer R, Oron Y \& Shalgi R 2005 Strontium-induced rat egg activation. Reproduction 130 467-474. (doi:10.1530/rep.1.00746)

Turinetto V, Orlando L, Sanchez-Ripoll Y, Kumpfmueller B, Storm MP, Porcedda P, Minieri V, Saviozzi S, Accomasso L, Cibrario Rocchietti E et al. 2012 High basal $\gamma \mathrm{H} 2 \mathrm{AX}$ levels sustain self-renewal of mouse embryonic and induced pluripotent stem cells. Stem Cells 30 1414-1423. (doi:10.1002/stem.1133)

West MH \& Bonner WM 1980 Histone 2A, a heteromorphous family of eight protein species. Biochemistry 193238-3245. (doi:10.1021/bi00555a022)

Whitworth KM \& Prather RS 2010 Somatic cell nuclear transfer efficiency: how can it be improved through nuclear remodeling and reprogramming? Molecular Reproduction and Development 77 1001-1015. (doi:10.1002/mrd.21242)

Wossidlo M, Arand J, Sebastiano V, Lepikhov K, Boiani M, Reinhardt R, Scholer H \& Walter J 2010 Dynamic link of DNA demethylation, DNA strand breaks and repair in mouse zygotes. EMBO Journal 29 1877-1888. (doi:10.1038/emboj.2010.80)

Xiao J, Liu Y, Li Z, Zhou Y, Lin H, Wu X, Chen M \& Xiao W 2012 Effects of the insemination of hydrogen peroxide-treated epididymal mouse spermatozoa on $\gamma \mathrm{H} 2 \mathrm{AX}$ repair and embryo development. PLOS ONE 7 e38742. (doi:10.1371/journal.pone.0038742)

Yin XJ, Tani T, Yonemura I, Kawakami M, Miyamoto K, Hasegawa R, Kato Y \& Tsunoda Y 2002 Production of cloned pigs from adult somatic cells by chemically assisted removal of maternal chromosomes. Biology of Reproduction 67 442-446. (doi:10.1095/biolreprod67.2.442)

Yoshioka K 2011 Development and application of a chemically defined medium for the in vitro production of porcine embryos. Journal of Reproduction and Development 57 9-16. (doi:10.1262/jrd. 10-196E)
Yoshioka K, Suzuki C, Tanaka A, Anas IM \& Iwamura S 2002 Birth of piglets derived from porcine zygotes cultured in a chemically defined medium. Biology of Reproduction 66 112-119. (doi:10.1095/biolreprod66.1.112)

Yukawa M, Oda S, Mitani H, Nagata M \& Aoki F 2007 Deficiency in the response to DNA double-strand breaks in mouse early preimplantation embryos. Biochemical and Biophysical Research Communications 358 578-584. (doi:10.1016/j.bbrc.2007.04.162)

Zhang D, Pan L, Yang L-H, He X-K, Huang X-Y \& Sun F-Z 2005 Strontium promotes calcium oscillations in mouse meiotic oocytes and early embryos through InsP3 receptors, and requires activation of phospholipase and the synergistic action of InsP3. Human Reproduction 20 3053-3061. (doi:10.1093/humrep/dei215)

Zheng P, Schramm RD \& Latham KE 2005 Developmental regulation and in vitro culture effects on expression of DNA repair and cell cycle checkpoint control genes in rhesus monkey oocytes and embryos. Biology of Reproduction 72 1359-1369. (doi:10.1095/biolreprod.104.039073)

Zhivotovsky B \& Kroemer G 2004 Apoptosis and genomic instability. Nature Reviews. Molecular Cell Biology 5 752-762. (doi:10.1038/ nrm1443)

Ziegler-Birling C, Helmrich A, Tora L \& Torres-Padilla ME 2009 Distribution of p53 binding protein 1 (53BP1) and phosphorylated H2A.X during mouse preimplantation development in the absence of DNA damage. International Journal of Developmental Biology $\mathbf{5 3}$ 1003-1011. (doi:10.1387/ijdb.082707cz)

Received 21 June 2013

Accepted 11 July 2013 